\title{
CONNECTIVITY IN SOL-GEL SILICA GLASSES
}

\author{
Wander L. Vasconcelos
}

Dept. of Metallurgical and Materials Engineering - UFMG - Rua Espírito Santo, 35 - 2 andar - 30160-030 - Belo Horizonte - MG

Recebido em 2/12/96; aceito em 17/6/97

\begin{abstract}
In this work it is carried out a review on structural parameters related to the evaluation of pore connectivity of nanostructures. The work describes parameters and methods of evaluation of geometric parameters. The concepts of connectivity are applied to silica gels and glasses obtained from sol-gel process. The study of pores connectivity was carried out using a combination of geometric modeling and experimental evaluation of specific surface area and pore volume. The permeability of the pore structure is evaluated and a permeability geometric factor, $\mathrm{Pg}$, is proposed.
\end{abstract}

Keywords: connectivity; permeability; sol-gel.

\section{INTRODUCTION}

Glasses obtained from conventional methods may present many levels of porosity ${ }^{1}$. Glasses exhibit lower densities than the crystals with the same chemical composition due to the presence of defects and lack of periodicity. Thus, molecular permeability in glasses is usually an important factor when one consider its application.

Besides defects of reduced dimensions, glasses may present larger scale porosity in both volume fraction and dimension of pores. Such glasses can be obtained, for instance, through the Vycor ${ }^{\circledR}$ method, in which the connected porosity is obtained by leaching of one of the phases ${ }^{1}$. The sol-gel method can be used to obtain gels and glasses with highly controlled porosity at nanometric scale ${ }^{2-5}$.

Practical uses of controlled porosity glasses range from membranes ${ }^{5}$, impregnation of other substances ${ }^{6-7}$, making of composites $^{5}$, etc.

An usual way of describing the structure of porous glasses involves the evaluation of volume fraction of pores $\left(\mathrm{V}_{\mathrm{V}}\right)$, surface area per unit volume $\left(\mathrm{S}_{\mathrm{V}}\right)$ and the average diameter of pores (D). Besides these geometric parameters, it is important to describe the connectivity of pores per unit volume $\left(\mathrm{G}_{\mathrm{V}}\right)^{7-8}$.

According to Rhines ${ }^{10}$, the connectivity (or genus) of an isolated volume is defined as the number of independent closed curves that may be constructed within the volume which cannot be smoothly deformed into each other, nor shrunk to a point, without leaving the volume.

The objective of this work is to apply a geometric model ${ }^{11}$ in order to describe the connectivity of the porous structure of silica gels and glasses made via sol-gel method.

\section{DEVELOPMENT}

Topological parameters (e.g., connectivity) can be obtained by using serial sectioning technique. This technique requires visualization and recording of a sequence of bidimensional sections of the microstructure at known intervals ${ }^{12}$. Once the tridimensional image is reconstructed based on the sequence of bidimensional sections, one can obtain metric and topological parameters. The fundamental parameters that are commonly described are the genus $\left(\mathrm{G}_{\mathrm{V}}\right)$, number of nodes $\left(\mathrm{N}_{\mathrm{V}}\right)$, number of branches $\left(\mathrm{B}_{\mathrm{V}}\right)$ and number of features (or number of disjoined parts) $\left(\mathrm{P}_{\mathrm{V}}\right)$ per unit volume. These parameters are related by ${ }^{9}$

$\mathrm{G}_{\mathrm{V}}+\mathrm{N}_{\mathrm{V}}=\mathrm{B}_{\mathrm{V}}+\mathrm{P}_{\mathrm{V}}$
In order to obtain such parameters for a small scale structure or a structure hard to be visualized directly, one can use geometric modeling ${ }^{11}$. As used in this work, geometric modeling involves the following basic considerations:

1. It is difficult to observe the pore structure of gels and glasses obtained from alkoxide sol-gel method, because of its nanometric size.

2. Silica gels are permeable, suggesting the presence of an interconnected nanostructure.

3. The experimental technique most widely used to access the porous structure of silica gels is gas adsorption, using BET theory and considering a cylindrical shape for pores.

Taking into account such considerations it was developed a geometric model ${ }^{11}$, considering cylindrical shape for pores $(\mathrm{Fi}-$ gure 1). The cylindrical model is based on the assumption that all the volume and all the surface area are associated with the cylindrical branches of the structure. In this case a node represents the point where the branches meet and it has no volume associated to it.

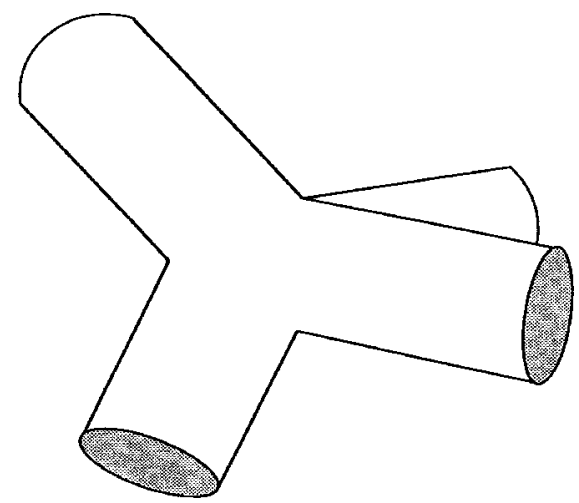

Figure 1. Cylindrical geometric model.

Considering $\mathrm{D}$ as the diameter of the cylinder and $\mathrm{L}$ as the average size of a cylindrical branch, the volume of a branch $(\mathrm{Vb})$ is given by ${ }^{11}$

$\mathrm{Vb}=\left(\pi \mathrm{D}^{2} \mathrm{~L}\right) / 4$,

while the surface area of a branch $(\mathrm{Sb})$ is given by ${ }^{11}$

$\mathrm{Sb}=\pi \mathrm{DL}$ 
$\mathrm{Vb}$ and $\mathrm{Sb}$ can be related to $\mathrm{V}_{\mathrm{V}}$ and $\mathrm{S}_{\mathrm{V}}$ by the following equations $^{11}$ :

$\mathrm{V}_{\mathrm{V}}=\left(\pi \mathrm{B}_{\mathrm{V}} \mathrm{D}^{2} \mathrm{~L}\right) / 4$

and

$\mathrm{S}_{\mathrm{V}}=\pi \mathrm{B}_{\mathrm{V}} \mathrm{D} \mathrm{L}$

From Eq. (4) one can obtain $\mathrm{B}_{\mathrm{V}}$ by ${ }^{11}$

$\mathrm{B}_{\mathrm{V}}=\left(4 \mathrm{~V}_{\mathrm{V}}\right) /\left(\pi \mathrm{D}^{2} \mathrm{~L}\right)$

Assuming that ${ }^{8}$

$\mathrm{L}=\left(4\left(1-\mathrm{V}_{\mathrm{V}}\right)\right) / \mathrm{S}_{\mathrm{V}}$

and considering ${ }^{8}$

$\mathrm{D}=4 \mathrm{~V}_{\mathrm{V}} / \mathrm{S}_{\mathrm{V}}$,

Bv can be written as

$\mathrm{B}_{\mathrm{V}}=\mathrm{S}_{\mathrm{V}}^{3} /\left(16 \pi \mathrm{V}_{\mathrm{V}}\left(1-\mathrm{V}_{\mathrm{V}}\right)\right)$

Eq. (9) can be used directly, replacing $S_{V}$ and $V_{V}$ by experimentally obtained data. In order to get $\mathrm{G}_{\mathrm{V}}$ values (Eq. (1)), one can assume for the gels in the dried stage, that $P_{V}=1$ (meaning one pore completely connected). Since the coordination number of pores $(\mathrm{CN})$ is assumed ${ }^{11}$ constant at $4, N_{V}$ becomes half of the $B_{V}$ value. When $C N$ vary (e.g., during densification) one has to use a more general form of the model ${ }^{11}$.

The silica gels used in this work were made by mixing TMOS, DI water and nitric acid. The gels were dried at $100{ }^{\circ} \mathrm{C}$ in an open air oven. Process variables chosen to be analyzed were the type of chemical precursor $\left(\mathrm{HNO}_{3}, \mathrm{HCl}, \mathrm{HOAc}\right.$ and $\mathrm{HF}$ ) and, for $\mathrm{HNO}_{3}$ gels, the $\mathrm{pH}$ (from 0.27 to 3.67).

The bulk density data of the silica gels were obtained using mercury pycnometry.

The pore structure of the silica gels was evaluated through nitrogen adsorption (BET), giving rise to data on $\mathrm{Sp}$ and $\mathrm{Vp}$ (surface area and volume of pores per gram). The equipment used was an automatic gas adsorption system Autosorb-1 (Quantachrome). In order to transform the $\mathrm{Sp}$ and $\mathrm{Vp}$ values in $\mathrm{S}_{\mathrm{V}}$ and $\mathrm{V}_{\mathrm{V}}$, it was assumed a true density of $2.2 \mathrm{~g} / \mathrm{cm}^{3}$.

Once the results of $\mathrm{V}_{\mathrm{V}}$ and $\mathrm{S}_{\mathrm{V}}$ were brought about, the cylindrical model was applied and the topological parameters $\mathrm{B}_{\mathrm{V}}, \mathrm{N}_{\mathrm{V}}, \mathrm{P}_{\mathrm{V}}$ and $\mathrm{G}_{\mathrm{V}}$ were obtained, as well as the permeability $(\mathrm{Kp})$ of the gels.

\section{RESULTS AND DISCUSSION}

The bulk density, specific surface area, specific volume and estimated average pore diameter of silica-gels catalyzed $(\mathrm{pH}=$ 1.5) with $\mathrm{HNO}_{3}, \mathrm{HCl}, \mathrm{HOAc}$ and $\mathrm{HF}$ are shown in table 1 . The bulk density of the gels changed from $0.87 \mathrm{~g} / \mathrm{cm}^{3}$, for gels catalyzed with $\mathrm{HF}$, up to $1.22 \mathrm{~g} / \mathrm{cm}^{3}$, for $\mathrm{HNO}_{3}$ (catalyzed) gels. The average pore diameter observed was $2.1 \mathrm{~nm}$ for $\mathrm{HNO}_{3}$ gels and $9.3 \mathrm{~nm}$ for $\mathrm{HF}$ gels.

Table 1. Structural data of silica gel porous matrices for $\mathrm{pH}$ 1.5.

\begin{tabular}{lcccc}
\hline Catalyzer & $\begin{array}{c}\text { Bulk } \\
\text { density } \\
\left(\mathrm{g} / \mathrm{cm}^{3}\right)\end{array}$ & $\begin{array}{c}\text { Specific } \\
\text { surface area } \\
\left(\mathrm{m}^{2} / \mathrm{g}\right)\end{array}$ & $\begin{array}{c}\text { Specific } \\
\text { volume } \\
\left(\mathrm{cm}^{3} / \mathrm{g}\right)\end{array}$ & $\begin{array}{c}\text { Average } \\
\text { pore diameter } \\
(\mathrm{nm})\end{array}$ \\
\hline $\mathrm{HNO}_{3}$ & 1.22 & 758 & 0.40 & 2.1 \\
$\mathrm{HCl}$ & 1.20 & 739 & 0.43 & 2.4 \\
$\mathrm{HOAc}$ & 1.05 & 777 & 0.57 & 2.9 \\
$\mathrm{HF}$ & 0.87 & 439 & 1.02 & 9.3 \\
\hline
\end{tabular}

Applying the cylindrical model (Eq. (9) and Eq. (1)) to the pore structure of the gels, one obtains the topological data shown in table 2. The observed volume fraction of pores varied from 0.47 for $\mathrm{HNO}_{3}$ gels up to 0.69 for HF gels. The connectivity of pores per unit volume $\left(\mathrm{G}_{\mathrm{V}}\right)$, varied from $4.20 \times 10^{19} \mathrm{~cm}^{-3}$ for $\mathrm{HF}$ gels up to $2.01 \times 10^{20} \mathrm{~cm}^{-3}$ for HOAc gels.

Table 2. Metric and topological data of silica gel porous matrices for $\mathrm{pH} 1.5$.

\begin{tabular}{lcccc}
\hline Catalyzer & $\begin{array}{c}\text { Surface } \\
\text { area } \\
\left(\mathrm{S}_{\mathrm{V}}\right) \\
\left(\mathrm{cm}^{-1}\right)\end{array}$ & $\begin{array}{c}\text { Volume } \\
\text { fraction of } \\
\text { pores } \\
\left(\mathrm{V}_{\mathrm{V}}\right)\end{array}$ & $\begin{array}{c}\text { Number of } \\
\text { branches } \\
\left(\mathrm{B}_{\mathrm{V}}\right) \\
\left(\mathrm{cm}^{-3}\right)\end{array}$ & $\begin{array}{c}\text { Connectivity } \\
\left(\mathrm{G}_{\mathrm{V}}\right)\end{array}$ \\
\hline $\mathrm{HNO}_{3}$ & $1.67 \mathrm{E}+07$ & 0.47 & $3.71 \mathrm{E}+20$ & $1.85 \mathrm{E}+20$ \\
$\left(\mathrm{~cm}^{-3}\right)$
\end{tabular}

The bulk density, specific surface area, specific volume and estimated average pore diameter of silica-gels catalyzed with $\mathrm{HNO}_{3}$ at $\mathrm{pH}$ 's varying from 0.27 to 3.67 are shown in table 3 . These results show how the $\mathrm{pH}$ of the aqueous solution influences the pore structure of the gels. The average pore diameter varied from $0.8 \mathrm{~nm}$ for $\mathrm{pH} 1.01$ up to $8.7 \mathrm{~nm}$ for $\mathrm{pH} 3.67$.

Table 3. Structural data of $\mathrm{HNO}_{3}$ silica gel porous matrices with varying $\mathrm{pH}$ 's.

\begin{tabular}{ccccc}
\hline $\mathrm{pH}$ & $\begin{array}{c}\text { Bulk } \\
\text { density } \\
\left(\mathrm{g} / \mathrm{cm}^{3}\right)\end{array}$ & $\begin{array}{c}\text { Specific } \\
\text { surface area } \\
\left(\mathrm{m}^{2} / \mathrm{g}\right)\end{array}$ & $\begin{array}{c}\text { Specific } \\
\text { volume } \\
\left(\mathrm{cm}^{3} / \mathrm{g}\right)\end{array}$ & $\begin{array}{c}\text { Average pore } \\
\text { diameter } \\
(\mathrm{nm})\end{array}$ \\
\hline 0.27 & 1.14 & 700 & 0.33 & 1.9 \\
1.01 & 1.44 & 722 & 0.15 & 0.8 \\
1.50 & 1.22 & 758 & 0.40 & 2.1 \\
2.00 & 1.09 & 693 & 0.38 & 2.2 \\
2.80 & 0.80 & 341 & 0.71 & 8.3 \\
3.67 & 0.80 & 327 & 0.71 & 8.7 \\
\hline
\end{tabular}

From the data shown in table 3 , one obtains the metric and topological data presented in table 4 . The connectivity of pores changed from $1.56 \times 10^{19} \mathrm{~cm}^{-3}$ for $\mathrm{pH} 3.67$ up to $2.14 \times 10^{20} \mathrm{~cm}^{-}$ ${ }^{3}$ for $\mathrm{pH} 1.01$.

Table 4. Metric and topological data of silica gel porous matrices catalyzed with $\mathrm{HNO}_{3}$ and with varying $\mathrm{pH}$ 's.

\begin{tabular}{ccccc}
\hline $\mathrm{pH}$ & $\begin{array}{c}\text { Surface } \\
\text { area } \\
\left(\mathrm{S}_{\mathrm{V}}\right) \\
\left(\mathrm{cm}^{-1}\right)\end{array}$ & $\begin{array}{c}\text { Volume } \\
\text { fraction of } \\
\text { pores } \\
\left(\mathrm{V}_{\mathrm{V}}\right)\end{array}$ & $\begin{array}{c}\text { Number of } \\
\text { branches } \\
\left(\mathrm{B}_{\mathrm{V}}\right) \\
\left(\mathrm{cm}^{-3}\right)\end{array}$ & $\begin{array}{c}\text { Connectivity } \\
\left(\mathrm{G}_{\mathrm{V}}\right)\end{array}$ \\
\hline 0.27 & $1.54 \mathrm{E}+07$ & 0.42 & $2.98 \mathrm{E}+20$ & $1.49 \mathrm{E}+20$ \\
$\left(\mathrm{~cm}^{-3}\right)$
\end{tabular}

A common expression used to estimate the permeability $(\mathrm{Kp})$ is given by ${ }^{13}$

$\mathrm{Kp}=\left(\mathrm{D}^{2} \mathrm{~V}_{\mathrm{V}}\right) / 4 \mathrm{k}$,

where $\mathrm{k}$ is a constant associated with the tortuosity of the pore 
network (usually 8 for cylindrical shape of pores). Applying Eq. (10) to the data shown in table 3, one obtains the permeability of the gels, shown in table $5 . \mathrm{Kp}$ varies from $5.35 \times 10^{-20} \mathrm{~m}^{2}$ for $\mathrm{pH} 1.01$ up to $1.44 \times 10^{-17} \mathrm{~m}^{2}$ for $\mathrm{pH} 3.67$.

Table 5. Permeability (Kp) and the permeability geometric factor $(\mathrm{Pg})$ of silica gel porous matrices catalyzed with $\mathrm{HNO}_{3}$ and with varying $\mathrm{pH}$ 's.

\begin{tabular}{ccc}
\hline $\mathrm{pH}$ & $\begin{array}{c}\text { Permeability } \\
(\mathrm{Kp})\end{array}$ & $\begin{array}{c}\text { Permeability } \\
\text { geometric factor } \\
(\mathrm{Pg}) \\
\left(\mathrm{m}^{-1}\right)\end{array}$ \\
\hline 0.27 & $4.67 \mathrm{E}-19$ & $2.23 \mathrm{E}+08$ \\
1.01 & $5.35 \mathrm{E}-20$ & $3.66 \mathrm{E}+07$ \\
1.50 & $6.52 \mathrm{E}-19$ & $3.86 \mathrm{E}+08$ \\
2.00 & $6.85 \mathrm{E}-19$ & $3.11 \mathrm{E}+08$ \\
2.80 & $1.32 \mathrm{E}-17$ & $7.46 \mathrm{E}+08$ \\
3.67 & $1.44 \mathrm{E}-17$ & $7.16 \mathrm{E}+08$ \\
\hline
\end{tabular}

In order to consider the connectivity in the evaluation of permeability it is proposed a expression for a permeability geometric factor, $\mathrm{Pg}$, which is obtained by introducing $\mathrm{G}_{\mathrm{V}}$ directly into Eq. (10):

$P g=\left(D^{2} V_{V} G_{V}\right) / 4 k$.

Introducing $G_{V}$, the units of $\mathrm{Pg}$ are changed from $\mathrm{m}^{2}$ (usual for $\mathrm{Kp}$ ) to $\mathrm{m}^{-1}$.

Applying Eq. (11) to the data shown in table 3 one gets the results presented in table 5 .

The pore network of the porous glasses can be evaluated using not only the usual metric parameters $\left(\mathrm{V}_{\mathrm{V}}, \mathrm{S}_{\mathrm{V}}\right.$ and $\left.\mathrm{D}\right)$, but topological parameters $\left(\mathrm{G}_{\mathrm{V}}\right)$ as well. Since the permeability of a porous material depends also on the connectivity, it seems to be natural to include the genus in the equation of permeability, giving rise to the permeability geometric factor, $\mathrm{Pg}$.

Based upon the results of this work, one can observe that by changing the type of the catalyzer and the $\mathrm{pH}$ of the aqueous solution, it is possible to control the pore structure and the permeability of the silica gels. As the $\mathrm{pH}$ of the solution is shifted from its isoelectric point (around $\mathrm{pH}=2)^{14}$, the presence of surface charges gives rise to more opened structures. The acid concentration influences the rates of hydrolysis $\left(\mathrm{k}_{\mathrm{H}}\right)$ and condensation $\left(\mathrm{k}_{\mathrm{C}}\right)$. As the ratio $\mathrm{k}_{\mathrm{H}} / \mathrm{k}_{\mathrm{C}}$ decreases, the gel presents a more branched (pore) network ${ }^{15}$. These results can be used to tailor the nanostructure of silica gels for applications such as molecular membranes for separation processes.

\section{CONCLUSION}

Topological parameters were obtained by applying a geometric model on the nanometric pore structure of silica gels and glasses. It is proposed a permeability geometric factor $(\mathrm{Pg})$, which considers the connectivity of the pore network.

\section{ACKNOWLEDGMENTS}

The author thanks FINEP/PADCT and CNPq for financial support.

\section{REFERENCES}

1. Vogel, W.; Chemistry of Glass; The American Ceramic Society; Columbus, Ohio, 1985.

2. Hench, L. L.; Vasconcelos, W. L.; Annu. Rev. Mat. Sci. 1990, 20, 269.

3. Zerda, T. W.; Vasconcelos, W. L.; Hench, L. L.; J. NonCryst. Solids. 1990, 121, 143.

4. Strawbridge, I.; James, P. F.; Glass Formation From Gels. In High Performance Glasses; Cable, M., Ed.; Blackie; Glasgow, 1992. p.20-49.

5. Vasconcelos, W. L.; Porous Silica Glasses. In Anais do Primeiro Simpósio Nacional de Vidros; Águas de Lindóia 1995. p.92-102.

6. Costa, V. C.; Vasconcelos, W. L.; Prenazzi, A.; Processing of Porous Silica Gels for Optical Components. In Sol-Gel Optics III; Mackenzie, J. D., Ed.; SPIE; San Diego 1994, p.717-23.

7. Fardad, M. A.; Yeatman, E. M.; Dawnay, E. J. C.; In SolGel Optics III; Mackenzie, J. D.; Ed.; SPIE; San Diego 1994; p.77-86.

8. Rhines, F. N.; Microstructology; Dr. Riederer-Verlag; Stuttgart 1986.

9. Vasconcelos, W. L.; DeHoff, R. T.; Hench, L. L.; J. NonCryst. Solids. 1990, 121, 124.

10. Rhines, F. N.; DeHoff, R. T.; Kronsbein, J.; A Topological Study of the Sintering Process; Final Report for the U.S. Atomic Energy Commission; University of Florida; Gainesville 1969.

11. Vasconcelos, W. L.; Hench, L. L.; Cerâmica 1992, 38, 17.

12. DeHoff, R. T.; Aigeltinger, E. H.; Craig, K. R.; J. Microsc. 1972, 95, 69.

13. Reed, J. E.; Introduction to the Principles of Ceramic Processing; John Wiley; New York 1988.

14. Iler, R. K.; The Chemistry of Silica; John Wiley; New York, 1979.

15. Brinker, C. J.; Scherer, G. W.; In Ultrastructure Processing of Ceramics, Glasses and Composites; Hench, L. L.; Ulrich, D. R., Ed.; John Wiley; New York, 1984. p. 43-59. 